\title{
Membangun Sistem Ekonomi Berkeadilan: Telaah atas Pemikiran Muhammad Baqir Al-Ṣadr
}

\author{
Agus Waluyo Nur \\ STAIN Salatiga J1. Tentara Pelajar No. 02 Salatiga \\ E-mail: aagwal@yahoo.com
}

\begin{abstract}
:
This writing is aimed to explore the Baqir Sadr's ideas on Islamic economics. It is important that his ideas have fundamental differences with other Islamic economic thinkers. They have an argument that the economic problems are caused by the scarcity of economic resources comparing with unlimited human needs. But according to Sadr, economic problems are caused by the uneven distribution of wealth. Șadr also distinguishes between economic sciences with the economic doctrine. Islamic economics is not theoretical sciences, but it is a doctrine of Islam in pursuit of economic life. His basic ideas of Islamic economic was contained in his writing (Iqtișādunā) which studied the theory of production and distribution. Unlike the known Islamic economics at the moment, the Islamic economic system on Șadr's perspective is more comprehensive, profound, and rooted on Islamic justice values.
\end{abstract}

Keywords: science, doctrine, economic system, justice, distribution

\section{Pandahuluan}

Munculnya sistem dan aliran ekonomi sesungguhnya bertujuan untuk mewujudkan masyarakat yang adil dan sejahtera. Kapitalisme misalnya, berasumsi bahwa dalam sistemnya terdapat suatu distribusi pendapatan dan kekayaan yang merata dan fair. Namun dalam kenyataannya sistem ini telah gagal mewujudkan tatanan masyarakat yang adil dan sejahtera, sehingga dianggap telah mati. Sistem ekonomi yang berkembang di kalangan kaum kapitalis ini merupakan implementasi dari nilai-nilai sekularisme yang merupakan asas ideologi sekaligus kaidah berpikir mereka. Demi kelanjutan sekularisme, maka ideologi kapitalisme selalu menjamin dan mempertahankan kebebasan individu. Di bawah nilai-nilai kebebasan, dibangunlah pe- 
mikiran cabang sistem ekonomi kapitalis. Artinya Kapitalisme telah memandang bahwa manusia hidup di dunia ini bebas untuk mengatur kehidupannya dan tidak boleh dicampuri oleh agama.

Ilmu ekonomi konvensional juga dianggap telah mempersulit situasi perekonomian global, bahkan gagal menciptakan keadilan sosial dan menyelesaikan persoalan manusia, baik secara nasional maupun internasional. Buku Ekspose Ekonomika karya Sri-Edi Swasono (2005) telah menunjukkan kegagalan ekonomi konvensional dalam konteks Indonesia. Secara internasional, buku The Death of Economics karya Ormerod (1998) dan buku Economics as Religion karya Nelson (2001) juga telah menunjukkan kegagalan ekonomi konvensional. Adanya kegagalan tersebut, telah mendorong perkembangan yang positif, di mana pakar-pakar ekonomi telah melakukan kritik tajam terhadap kegagalan ilmu ekonomi konvensional kapitalis dan menyumbangkan pemikirannya dengan mengemukakan ideide yang mengarah kepada perbaikan paradigma ilmu ekonomi menuju yang lebih baik, yaitu perhatian terhadap nilai-nilai moral, etik, dan keadilan sosial.

Dalam khazanah pemikiran Islam kontemporer dewasa ini, muncul gagasan untuk menggantikan sistem ekonomi konvensional dengan ekonomi Islam. Tawaran gagasan tersebut didorong atas kegagalan Kapitalisme dalam membangun ekonomi yang berkeadilan. Paradigma baru tersebut merupakan titik balik peradaban demi mengembangkan paradigma ekonomi yang memiliki nilai dan norma. Menurut Khursid Ahmad, dalam pengantar bukunya M. Umer Chapra (2001), perubahan paradigma ekonomi merupakan keharusan, karena paradigma ekonomi kapitalis telah mengabaikan nilainilai etika dan sosial. Oleh karena itu pergeseran paradigma (shifting paradigm) dalam ekonomi merupakan kebutuhan mendesak untuk dilaksanakan. Dengan kehadiran ekonomi Islam diharapkan dapat menjadi salah satu upaya untuk keluar dari kegagalan dan kekacauan sistem ekonomi dunia, Kapitalisme dan Sosialisme.

Era globalisasi (the age of globalization) yang dalam beberapa literatur dinyatakan bermula pada dekade 1990-an (Pervez, 2004: 280), dan ditandai dengan adanya fenomena penting dalam bidang ekonomi, merupakan tantangan sekaligus peluang bagi ekonomi Islam. Kegiatan ekonomi dunia yang tidak hanya dibatasi oleh faktor batas geografi, bahasa, budaya dan 
ideologi, namun juga faktor saling membutuhkan dan saling bergantung satu sama lain (Jan Pronk, 2001: 43), memberi kesempatan kepada semua untuk saling berlomba. Dunia menjadi seakan-akan tidak ada batas, terutama karena perkembangan teknologi informasi yang begitu pesat. Keadaan yang demikian melahirkan banyak peluang sekaligus tantangan, terutamanya dalam upaya pengembangan ekonomi Islam (Walter, 2004: 18-19). Dalam konteks upaya pengembangan ekonomi Islam, gagasan Muhammad Baqir al-Sạdr (selanjutnya disebut Sadr) tentang ekonomi Islam perlu dikaji secara mendalam sehingga dapat dijadikan alternatif.

\section{Sekilas tentang Baqir Al-Ṣadr}

Ṣadr lahir di sebuah kota kecil bernama Khaẓimiyah Baghdad Irak pada tanggal 1 Maret $1935 \mathrm{M}$ bertepatan pada tanggal 25 Dzul-Qa' 'dah $1353 \mathrm{H}$ (Mallat, 2000: 21). Ia merupakan salah seorang keturunan dari keluarga sarjana dan intelektual yang menganut paham Syi'ah. Sadr merupakan anak kedua dari tiga bersaudara. Pada usia empat tahun, ia kehilangan ayahnya, dan kemudian diasuh oleh ibunya yang religius dan kakak lakilakinya, Ismail, yang juga seorang mujtahid kenamaan di Irak. Kondisi kemiskinan keluarga Șadr memberikan inspirasi kepada salah seorang pamannya yang bernama Murtaḍa al-Yasin untuk menangani pendidikannya.

Pendidikan Șadr dimulai di SD Muntada al-Nashr di Khaẓimiyyah. Di tempat ini ia belajar fiqh, uṣul fiqh dan teologi. Ia dibesarkan dalam lingkungan intelektual dan religius sehingga tidak heran sejak kecil telah menunjukkan superioritas intelektualnya. Selain mengikuti proses belajar formal, ia banyak mengembangkan keilmuan secara otodidak. Menurut Mallat (2001: 22), prestasi intelektualnya sangat menonjol dan mengagumkan. Ia menunjukkan tanda-tanda kejeniusan sejak usia kanak-kanak. Menurut Mallat (2001: 253), kecerdasan dan kepandaiannya secara genetik diwarisi dari silsilah keluarganya. Kakek buyutnya, Sadruddin al Amili adalah seorang penuntut ilmu yang gigih. Sedangkan kakeknya, Ismail Șadr mendapat kepercayaan untuk mengelola Hauzah (pusat studi Islam). Lalu ayahnya, Haidar seorang marja' (rujukan imu) terkemuka di kotanya. Ketika berusia sepuluh tahun, ia telah mampu berorasi sejarah dan kebudayaan, bahkan pada usia sebelas tahun sudah mengambil studi logika dan mampu 
menulis buku yang berisi kritik atas para filosof. Ia mampu menangkap isuisu teologis yang sulit dan bahkan tanpa bantuan seorang guru. Pada usia tiga belas tahun, kakaknya mengajarkan kepadanya Ușūl 'ilm al-fiqh. Setelah menginjak dewasa (berusia sekitar 16 tahun), ia pergi ke Najaf yang memiliki kultur dan corak khusus untuk menuntut pendidikan yang lebih baik dalam berbagai cabang ilmu-ilmu islami. Sekitar empat tahun kemudian, ia menulis sebuah ensiklopedi tentang Ușūl Ghāyat al-Fikr fî̀ al-Ușūl.

Latar belakang pemikirannya yang bercorak rasionalistik menyebabkan S. adr banyak bersentuhan dengan dunia filsafat dan sosiologis. Pengalaman intelektual tersebut telah menjadikan Șadr tumbuh menjadi pemuda yang berkarakter serta memiliki kapasitas keilmuan yang komprehensif. Dalam usianya yang relatif muda (sekitar tiga puluh tahun), ia telah menjadi mujtahid mutlak sekaligus pemikir ekonomi Islam yang menguasai ilmu-ilmu filsafat, tafsir serta hadis. Ia termasuk salah seorang pemikir kontemporer yang akrab dengan karya-karya pemikir Islam klasik maupun modern. Șadr juga mampu berbicara dengan fasih tentang pemikiranpemikiran Barat yang berkembang dan mendapatkan perhatian besar dari kalangan umat Islam maupun non-muslim. Dengan kejernihan dan kecerdasan pemikirannya, ia mampu menepis kesan apologi yang selama ini melekat pada pemikir Islam. Sebagai salah seorang pemikir terkemuka, Șadr melambangkan kebangkitan intelektual yang berlangsung di Najaf antara tahun 1950-1980. Ia diibaratkan sebuah ensiklopedia yang mendemonstrasikan metodologi fiqh, ușūl fiqh, prinsip-prinsip logika, epistemologi dan ekonomi. Gaya pembahasannya pun berbeda dengan ulama lain.

Sekalipun memiliki latar belakang pendidikan tradisional, Șadr memiliki minat intelektual yang tinggi dan seringkali bersinggungan dengan isu-isu kontemporer. Dua karya masterpiece yang mewakili pemikirannya dalam bidang filsafat dan ekonomi dapat dirujuk dalam Falsafatunā dan Iqtiṣādunā. Dengan kedua karyanya tersebut, ia dengan fasih mengutarakan kritik terhadap pemikiran Barat seperti Karl Marx, Descartes, dan John Locke. Bahkan ia juga mengkritisi terhadap aliran Marxisme dan Kapitalisme. Sadr juga menyampaikan pandangan ilmiah berupa kritikan atas filsafat materialisme Barat. Pandangan-pandangan brilian ilmiah Șadr semakin bermakna ketika ia terjun ke dunia politik praktis yang secara tidak langsung 
menarik perhatian aktivis politik di Irak. Șadr termasuk pendukung revolusi Islam Iran di bawah pimpinan Imam Khomeini. Berkali-kali ia melakukan korespondensi dengan Imam Khomeini. Melalui surat-suratnya itu, ia terusmenerus menunjukkan dukungan dan kesetiaannya terhadap gerakan revolusi di Iran. Hal inilah yang membuat Rezim Baats menganggap Șadr sebagai tokoh yang membahayakan kepentingan mereka. Saddam kemudian menangkap Șadr beserta adik perempuannya, Bint al-Huda. Bahkan Saddam melakukan eksekusi hukuman gantung terhadap keduanya pada 8 April 1980. Tindakan rezim Saddam ini membangkitkan gelombang protes dari banyak kalangan di Irak sehingga menjadi titik puncak tantangan terhadap Islam di Irak.

Dengan meninggalnya Șadr, Irak kehilangan aktivis Islamnya yang paling penting. Setelah eksekusi tersebut, ternyata Șadr justru semakin dikenal, dan reputasinya diakui masyarakat. Namanya telah melintasi Mediterania, ke Eropa dan Amerika Serikat. Pada 1981, Hanna Batatu, dalam sebuah artikel di Middle East Journal di Washington, menunjukkan pentingnya Șadr bagi gerakan bawah tanah Syiah di Irak. Pada 1984, Iqtiṣādunā diterjemahkan ke dalam bahasa Jerman oleh orientalis muda Jerman. Kini karya-karyanya telah diterjemahkan ke berbagai bahasa.

\section{Ekonomi Islam antara Doktrin dan Ilmu}

Ekonomi Islam dapat didefinisikan sebagai sebuah studi tentang pengelolaan harta benda menurut perpektif Islam (Al-Nabhani, 1990). Menurut Muhammad Abdul Mannan (1986), ekonomi Islam adalah ilmu sosial yang mempelajari masalah-masalah ekonomi masyarakat dalam perspektif nilai-nilai Islam. Nejjatullah Siddiqie (1992) mendefinisikan ekonomi Islam sebagai tanggapan pemikir-pemikir muslim terhadap tantangan ekonomi pada zamannya, yang dibantu oleh Alquran dan Sunnah disertai dengan argumentasi dan pengalaman empirik.

Sistem Ekonomi Islam merupakan mazhab ekonomi, di mana Islam mengatur kehidupan perekonomian dengan nilai-nilai moral, ekonomi, dan sejarah perekonomian masyarakat. Sebagai sebuah sistem, ekonomi Islam merupakan ilmu ekonomi yang dilaksanakan dalam praktik sehari-hari bagi 
individu, keluarga, kelompok masyarakat, maupun pemerintah/penguasa, dalam rangka mengorganisasi faktor produksi, distribusi, dan pemanfaatan barang maupun jasa yang dihasilkan, agar tunduk dalam peraturan/perundangundangan Islam (sunnatullah). Sebagai sebuah sistem, ekonomi Islam berbeda dengan Kapitalisme, Sosialisme, maupun Negara Kesejahteraan. Islam menentang eksploitasi dan melarang penumpukan kekayaan. Dalam hal kekuasaan negara dan kebebasan perorangan, Islam berbeda dengan Sosialisme yang memandang negara memiliki otoritas penuh. Menurut Muslehuddin, Islam berbeda dengan Sosialisme, karena keadilan sosialekonomi menurut Islam memberikan wilayah yang luas agar setiap individu berkembang selama tidak bertentangan dengan kepentingan masyarakat. Sedangkan Sosialisme lebih menekankan pada individual dengan melarang kepemilikan kekayaan pribadi (Muslehuddin, 2004: 165-180). Selanjutnya, dalam Islam, etika dijadikan sebagai pedoman perilaku ekonomi. Sedangkan dalam Negara Kesejahteraan, yang ada adalah bebas nilai (Naqwi, 1994: 80). Oleh karena itu, Kuntowijoyo (1997) menyebutnya sebagai "ekonomi etik" (ethical economy) yang berlandaskan pada agama dan tanggung jawab sosial.

Umar Chapra (2001) menyebut ekonomi Islam dengan ekonomi Tauhid. Tujuan utamanya adalah merealisasikan tujuan manusia untuk mencapai kebahagiaan dunia dan akhirat (falāh), serta kehidupan yang baik dan terhormat (al-ḥayāh al-țayyibah). Ini merupakan definisi kesejahteraan dalam pandangan Islam, yang berbeda secara mendasar dengan pengertian kesejahteraan dalam ekonomi konvensional yang sekuler dan materialistik (Khan, 1989: 7). Menurut Zarqa' (1989: 29-38), tujuan sistem ekonomi Islam adalah terkait dengan tujuan yang tidak hanya memenuhi kesejahteraan hidup di dunia saja (materialis), namun juga kesejahteraan hidup yang lebih hakiki (akhirat), dengan mengedepankan pencarian keridhaan-Nya dalam segala pola perilaku sejak dari konsumsi, produksi hingga distribusi.

Dalam mendefinisikan ekonomi Islam, Șadr (2000) mencoba memberikan sebuah interpretasi baru yang bisa dikatakan original. Ia mulai membangun kerangka dasar dengan membuat perbedaan yang signifikan antara ilmu ekonomi dan doktrin ekonomi. Menurut Șadr, antara ilmu ekonomi dengan ideologi Islam terdapat perbedaan prinsip, karena keduanya 
berasal dari filosofi yang berbeda sehingga tidak bisa dicari titik temu antara keduanya. Menurut Ṣadr, ilmu ekonomi merupakan ilmu yang berhubungan dengan penjelasan terperinci perihal kehidupan ekonomi, peristiwa-peristiwa, gejala-gejala lahiriahnya, serta hubungan antara peristiwa dan fenomena tersebut dengan sebab dan faktor umum yang mempengaruhinya. Sedangkan doktrin ekonomi adalah cara atau metode yang dipilih dan diakui oleh suatu masyarakat dalam memecahkan setiap problem praktis ekonomi yang dihadapinya (Ṣadr, 2008: 79).

Dari hal tersebut, Șadr selanjutnya menyatakan bahwa perbedaan yang signifikan dari kedua terminologi di atas adalah bahwa doktrin ekonomi berisikan setiap aturan dasar dalam kehidupan ekonomi yang berhubungan dengan ideologi seperti nilai-nilai keadilan. Sedangkan ilmu ekonomi berisikan setiap teori yang menjelaskan realitas kehidupan ekonomi yang terpisah dari kerangka ideologi. Nilai-nilai keadilan inilah yang bagi Șadr merupakan tonggak pemisah antara gagasan doktrin ekonomi dengan teoriteori ilmiah ilmu ekonomi. Dengan demikian, Șadr menyimpulkan bahwa ekonomi Islam merupakan sebuah doktrin dan bukan merupakan suatu ilmu pengetahuan, karena ia adalah cara yang direkomendasikan Islam dalam mengejar kehidupan ekonomi, bukan merupakan suatu penafsiran Islam mengenai peristiwa-peristiwa yang terjadi dalam kehidupan ekonomi dan hukum-hukum yang berlaku di dalamnya (Ṣadr, 2008: 80).

Dalam ilmu ekonomi, masalah ekonomi disebabkan oleh masalah kelangkaan sumber daya ekonomi (scarcity) dibandingkan dengan kebutuhan manusia yang sifatnya tidak terbatas. Konsep kelangkaan (scarcity) ini tidak bisa diterima oleh Șadr, karena tidak selaras dengan pesan wahyu yang menjamin kehidupan setiap makhluk di bumi ini. Șadr menolak pengertian tersebut, sebab dalam Islam telah ditegaskan bahwa Allah S.W.T. telah menciptakan makhluk di dunia ini termasuk manusia dalam kecukupan sumber daya ekonomi. Hal ini didasarkan pada firman Allah dalam QS. AlFurqan ayat 2:

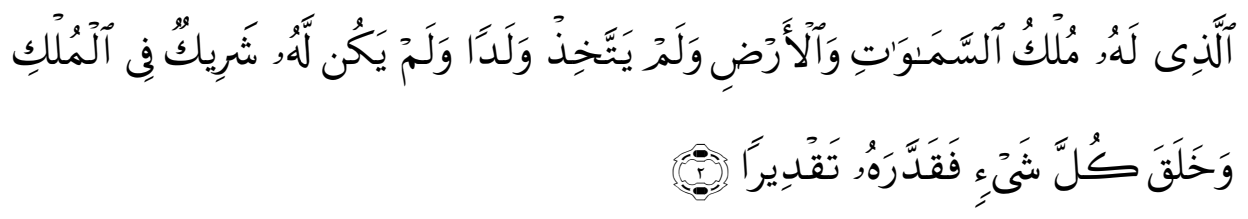


Artinya: "Yang kepunyaan-Nya-lah kerajaan langit dan bumi, dan Dia tidak mempunyai anak, dan tidak ada sekutu baginya dalam kekuasaan(Nya), dan Dia telah menciptakan segala sesuatu, dan Dia menetapkan ukuran-ukurannya dengan serapi-rapinya”.

Pada QS. Al-Qamar: 49, Allah juga berfirman:

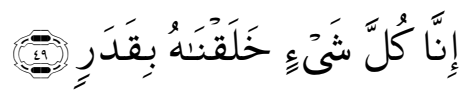

Artinya: "Sesungguhnya Kami menciptakan segala sesuatu menurut ukuran".

Pada sisi lain Șadr (2008) juga menolak anggapan bahwa kebutuhan manusia sifatnya tidak terbatas. Menurutnya, kebutuhan manusia sifatnya tidak tak terbatas sebagaimana dijelaskan dalam konsep law of diminishing marginal utility, bahwa semakin banyak barang dikonsumsi maka pada titik tertentu justru akan menyebabkan tambahan kepuasan dari setiap tambahan jumlah barang yang dikonsumsi akan semakin berkurang. Jadi ada kesenjangan pemikiran yang menimbulkan kekacauan persepsi antara pengertian kebutuhan (need) dan keinginan (want). Dalam perspektif ekonomi Islam, perilaku ekonomi harus didasarkan pada kebutuhan (need) yang disandarkan pada nilai-nilai syariah Islam, bukan didasarkan pada keinginan (want). Jika perilaku manusia disandarkan pada keinginan (want), maka persoalan ekonomi tidak akan pernah selesai, karena nafsu manusia selalu merasa tidak akan pernah puas. Di sinilah persoalan ekonomi yang dihadapi sekarang, karena bertitik tolak pada keinginan (want) masyarakat sehingga tekanan ekonomi menjadi semakin kuat yang berdampak pada ketidakseimbangan, baik secara makroekonomi maupun mikroekonomi. Salah satu efek yang ditimbulkan dari perilaku ekonomi yang bertitik tolak pada keinginan (want) yaitu semakin rusaknya sistem keseimbangan lingkungan hidup karena sumber-sumber daya ekonomi terkuras habis sekedar untuk memenuhi keinginan manusia yang tidak akan pernah puas. Di samping itu dalam aktivitas ekonomi, setiap tindakan yang dilakukan oleh seorang muslim harus disandarkan pada syariah Islam, baik dalam aktivitas konsumsi, produksi maupun distribusi. Moral ekonomi Islam yang didasarkan pada pengendalian 
hawa nafsu akan menjamin keberlangsungan (sustainability) kehidupan dan sumber daya ekonomi di dunia ini.

Menurut Sadr, masalah-masalah ekonomi lahir karena masalah distribusi kekayaan yang tidak merata. Ia merujuk firman Allah QS. Ibrahim ayat 32-34:

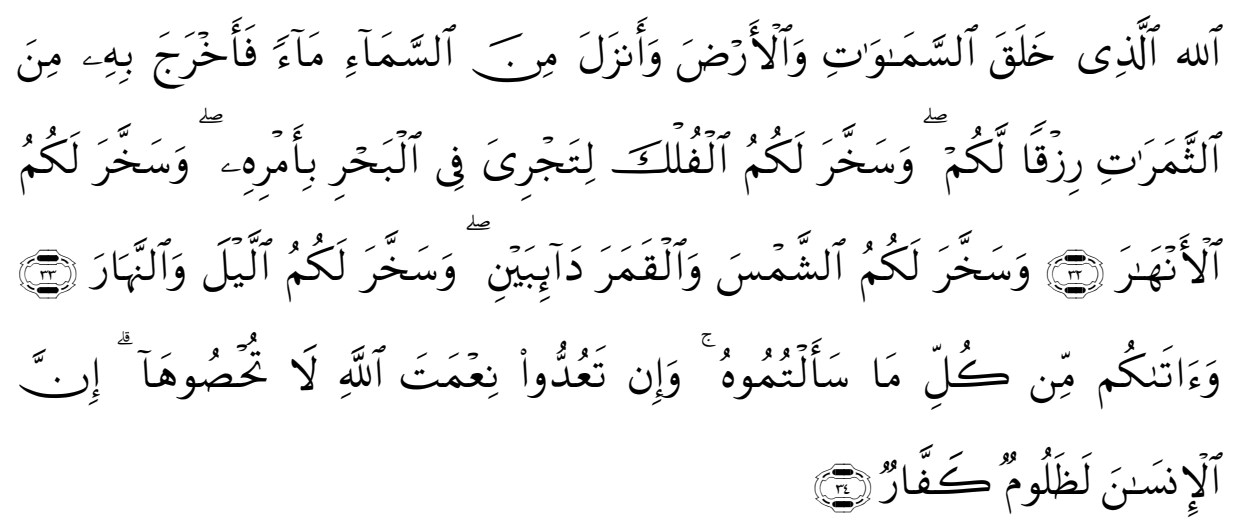

Artinya: "Allahlah yang telah menciptakan langit dan bumi dan menurunkan air hujan dari langit, kemudian Dia mengeluarkan dengan air hujan itu berbagai buah-buahan menjadi rezeki untukmu, dan dia telah menundukkan bahtera bagimu supaya bahtera itu berlayar di lautan dengan kehendak-Nya, dan dia telah menundukkan (pula) bagimu sungai-sungai. Dan Dia telah menundukkan (pula) bagimu matahari dan bulan yang terus menerus beredar (dalam orbitnya), dan telah menundukkan bagimu malam dan siang. Dan dia telah memberikan kepadamu (keperluanmu) dan segala apa yang kamu mohonkan kepadanya. dan jika kamu menghitung nikmat Allah, tidaklah dapat kamu menghitungnya. Sesungguhnya manusia itu sangat zalim dan sangat mengingkari (nikmat Allah)".

Merujuk ayat tersebut, S Sadr berpendapat bahwa permasalahan ekonomi muncul disebabkan oleh dua faktor yang mendasar, yaitu karena perilaku manusia yang melakukan kezaliman, dan karena mengingkari nikmat Allah s.w.t. Menurutnya potensi sumber daya ekonomi yang diciptakan Allah s.w.t. di alam semesta ini begitu melimpah, baik yang ada di darat maupun di laut. Jika dikelola dengan baik dan bijaksana niscaya semua individu di dunia dapat hidup secara layak dan manusiawi. Namun fakta membuktikan 
bahwa tidak semua manusia dapat menikmati anugerah Allah tersebut, sehingga masih banyak dari mereka yang hidup di bawah garis kemiskinan, sementara sebagian kecil lainnya bergelimang dalam kemewahan.

Adanya kesenjangan secara terminologis antara pengertian ekonomi dalam perspektif ekonomi konvensional dengan pengertian ekonomi dalam perspektif syariah Islam sebagaimana dijelaskan di atas, memerlukan adanya perumusan tentang ekonomi Islam dalam konteks syariah Islam. Menurut Șadr untuk mewujudkan hal tersebut, ada beberapa langkah yang dilakukan, yaitu: (1) mengganti istilah ilmu ekonomi dengan istilah iqtiṣād yang mengandung arti selaras, setara dan seimbang, dan (2) merekonstruksi ilmu ekonomi secara tersendiri, yang bersumber dari Alquran dan Sunnah. Hal lain yang ditawarkan Ṣadr adalah dengan menciptakan hubungan yang baik antara distribusi dan mobilisasi segenap sumber daya material untuk memakmurkan alam.

Dalam hal mempelajari illmu ekonomi, menurut Sadr harus dilihat dari dua aspek, yaitu aspek philosophy of economics atau normative economics dan aspek positive economics. Contoh dari aspek positive economics yaitu mempelajari teori konsumsi dan permintaan yang merupakan suatu fenomena umum dan dapat diterima oleh siapapun tanpa dipengaruhi oleh ideologi. Dalam teori konsumsi, dirumuskan bahwa faktor-faktor yang mempengaruhi konsumsi suatu barang adalah tingkat pendapatan, tingkat harga, selera dan faktor-faktor nonekonomi lainnya. Berdasarkan hukum permintaan (law of demand), ada korelasi yang negatif antara besarnya tingkat harga barang dengan jumlah barang yang diminta dengan asumsi ceteris paribus. Jika harga barang naik, maka jumlah barang yang diminta akan turun, dan sebaliknya. Fakta ini terjadi pada konteks ekonomi di manapun dan oleh siapapun tanpa melihat latar belakang sosial, budaya, agama, politik dan sebagainya.

Sedangkan dari aspek phylosophy of economics yang merupakan hasil pemikiran manusia, akan dijumpai bahwa setiap kelompok manusia mempunyai ideologi, cara pandang dan kebiasaan (habit) yang tidak sama. Persoalan kepantasan antara satu anggota masyarakat dengan anggota lainnya atau antara satu golongan masyarakat dengan golongan lainnya masing-masing memiliki batasan atau definisi sendiri. Makan sambil berdiri 
dan menggunakan tangan kiri merupakan masalah yang pantas dan biasa di masyarakat Eropa, namun lain halnya pada masyarakat di Indonesia. Dalam pandangan Islam bahwa sesuatu dianggap "pantas" manakala hal itu dianjurkan dalam Islam. Sesuatu dianggap "tidak pantas" jika hal itu dicela dan dilarang menurut syariah. Contoh lain misalnya menyangkut pembahasan keadilan. Menurut konsep Kapitalisme klasik yang dimaksud dengan "adil" adalah engkau memperoleh apa yang memang sudah sepatutnya (you get what you deserved). Sedangkan menurut kelompok Sosialisme klasik makna "adil" adalah tidak ada seorang pun yang mendapatkan hak istimewa untuk memperoleh sesuatu lebih dari yang lain (no one has privilege to get more than others). Tetapi Islam mempunyai makna tersendiri dalam memaknai "adil" yaitu tidak menzalimi dan tidak dizalimi (lā tazlimūna wa lā tuẓlamūna).

\section{Memperjuangkan Sistem Ekonomi Berkeadilan}

Sistem ekonomi merupakan sebuah konsep fundamental sekaligus mekanisme melakukan aktifitas ekonomi -produksi, distribusi dan konsumsi, sehingga menentukan arah kerja perekonomian sebuah negara. Sistem ekonomi memiliki pengaruh yang sangat besar dalam kehidupan masyarakat, karena dapat mempengaruhi keinginan dan aspirasi yang ingin dimiliki warga. Bahkan sistem tersebut juga menentukan kepribadian ideal seseorang (Rawls, 1971: 29). Sistem ekonomi yang dianut suatu negara ditentukan oleh arah kebijakannya untuk menyelesaikan problematika ekonomi dengan mengikuti perubahan zaman dan dinamika pasar. Secara garis besar, problematika ekonomi dapat dirinci dalam tiga pertanyaan, yaitu what, how, dan for whom (Samuelson, 1985: 495-499). Ketiga terminologi tersebut akan dipecahkan oleh setiap sistem ekonomi, baik masalah produksi, distribusi maupun konsumsi.

Keterpurukan ekonomi yang melanda dunia saat ini, tidak lain adalah akibat dari sistem Kapitalisme yang semata-mata berorientasi pada akumulasi kapital yang mengabaikan faktor-faktor penting dalam kehidupan, baik nilainilai moral maupun aspek kehati-hatian yang populis dengan manajemen risiko dalam diskursus ilmu ekonomi. Transaksi derivatif yang menjadi awal krisis dewasa ini adalah fakta konkret yang tidak bisa terbantahkan, bahwa memperoleh keuntungan dengan jalan spekulasi akan mendatangkan 
kerugian bagi manusia semata. Hal ini selaras dengan pandangan ekonom konvensional yang sekaligus mantan gubernur The Fad Alan Gleenspan yang menyatakan bahwa tingkat suku bunga rendah yang dalam satu sisi sebagai piranti untuk mengelola inflasi dalam kenyataannya melahirkan Bubble Economic yang dalam waktu dekat akan melahirkan dampak krisis ekonomi.

Paradigma sistem Kapitalisme yang hanya berorientasi pada akumulasi kapital semata dan mengabaikan peran nilai-nilai di luar kepentingan ekonomi akan memunculkan pada ketidakseimbangan ekonomi dalam masyarakat. Hal ini selaras dengan pandangan Karl Marx yang menyatakan bahwa sistem Kapitalisme merupakan sistem yang dipenuhi oleh sifat negatif. Sifat negatif tersebut dalam kenyataannya menguasai sifat positif dari Kapitalisme. Oleh karena itu, pembaharuan dan reformasi dalam sistem Kapitalisme tidak akan mampu menghilangkan sifat dasar negatif tersebut.

Kevin Danaher dalam bukunya "10 Reason Abolish IMF And World Bank" mengkritik kebusukan sistem Kapitalisme lewat jejaring 2 institusinya IMF dan World Bank. Menurut Kevin Danaher yang mengutip data dari The United Nations Development Program (UNDP), sebanyak 20\% kaum kaya di dunia tengah menikmati $86 \%$ sumber kekayaan dunia. Sedangkan $80 \%$ penduduk miskin di dunia hanya menikmati $14 \%$ sumber kekayaan dunia. Betapa ini merupakan sebuah ketimpangan yang tengah dihasilkan oleh sistem Kapitalisme yang ironisnya diterapkan hampir di seluruh belahan negara dunia. Pandangan serupa juga dapat diketemukan dalam pemikiran Fritjof Capra dalam bukunya "The Hidden Conections" yang mencoba menawarkan sebuah strategi melawan Kapitalisme baru. Menurut Capra, berbagai sistem terpadu yang mengitegrasi dimensi biologis, kognitif, dan sosial dari kehidupan, memperlihatkan bagaimana pemahaman komprehensif ini akan sangat penting bagi keberlangsungan hidup manusia. Menurut Capra, dewasa ini dunia sedang dihadapkan pada dua perkembangan yang sangat mempengaruhi manusia. Dua hal tersebut yakni kapitalisme global dan perencanaan eco-design yang dalam posisi saling bertabrakan. Oleh karena itu, bagi Capra yang harus dilakukan oleh manusia sekarang adalah mengubah tata nilai yang mendasari sistem perekonomian global dewasa ini. Tidak jauh dengan pandangan Capra, Anthony Gidden dalam bukunya The Thrid Way menyatakan dunia seyogyanya mencari jalan ketiga dari pergumulan 
sistem kakap dunia yakni Kapitalisme dan Sosialisme. Tumbangnya Komunisme Soviet Rusia dalam satu sisi juga telah mengisyaratkan akan ketidakberdayaan sistem ekonomi konvensional dalam memecahkan problem ekonomi yang dihadapi oleh manusia. Senada dengan hal ini, Francis Fukuyama melalui The End of History juga mengungkap hal yang sama. Dalam hal ini Gidden menyatakan, sistem alternatif adalah salah satu kunci untuk keluar dari permasalahan tersebut. Dengan runtuhnya Komunisme dan kegagalan kronis Kapitalisme dalam menyejahterakan sebagian besar umat manusia, sistem ekonomi Islam bisa menjadi alternatif solusi guna mengatasi berbagai permasalahan serta kebuntuan ekonomi yang ada dewasa ini.

Kehadiran sistem ekonomi Islam sebagai alternatif baru bukanlah gagasan awam, tetapi telah mendapat dukungan dari ekonom terkemuka dunia yang mendapat hadiah Nobel 1999, yaitu Joseph E. Stiglitz. Bersama Bruce Greenwald, Stiglitz menulis buku "Toward a New Paradigm in Monetary Economics" mencoba menawarkan paradigma baru dalam ekonomi moneter. Dalam buku tersebut mereka mengkritik teori ekonomi konvensional dengan mengemukakan pendekatan moneter baru yang merupakan sudut pandang ekonomi Islam di bidang moneter, seperti peranan uang, bunga, dan kredit perbankan.

The Economist dalam surveynya yang dikutip Ihsan Ali Fauzi (1995) menunjukkan bahwa institusi ekonomi yang terdapat dalam sistem ekonomi Islam sangat bermanfaat bagi perwujudan peradaban umat manusia secara keseluruhan. Sistem ekonomi Islam merupakan pilihan di tengah sistem ekonomi dunia saat ini dengan mekanisme pasarnya yang tidak lagi dapat dikendalikan oleh siapapun dan sistem manapun. Sistem ekonomi Islam hadir sebagai alternatif keberpihakan sistem ekonomi pada tatanan pasar yang berkeadilan dan bermanfaat serta mensejahterakan manusia. Sayyid Husin Nașr (2000) melihat bahwa instrumen ekonomi berkeadilan dapat ditemukan dalam sistem ekonomi Islam melalui pengelolaan zakat, infak, sadaqah dan wakaf yang bertujuan untuk mensejahterakan semua lapisan masyarakat.

Sistem Ekonomi Islam bukan sekedar sistem ekonomi tanpa bunga. Berlandaskan pada keadilan Islam yang universal, sistem ini mencakup dan menaungi seluruh aspek ekonomi dalam kehidupan manusia. Sistem ekonomi 
Islam adalah jalan tengah bagi kemanusiaan yang berangkat dari kesadaran tentang arti penting etika. Sistem ekonomi etik Islam berbeda dengan semua sistem ekonomi yang pernah ada. Baik ekonomi Kapitalis maupun Sosialis, semuanya berangkat dari adanya kepentingan (interest). Bahkan ekonomi Kapitalis berangkat dari kepentingan perorangan (selfishness), dan sistem Sosialis berangkat dari kepentingan yang bersifat kolektif (collectivism).

Pada tahap tersebut, Sadr mencoba menawarkan paradigma baru ekonomi Islam dengan mendekonstruksi ekonomi Kapitalisme menuju sistem ekonomi yang berkeadilan dan berketuhanan demi merealisasikan kesejahteraan manusia. Sistem ekonomi Barat dinyatakan telah gagal menciptakan kesejahteraan umat manusia yang merupakan tujuan utama dari kehadiran sebuah sistem ekonomi. Dalam membangun sistem ekonomi Islam, Șadr berangkat dari pandangan bahwa Islam dapat memberikan jalan untuk penegakan persaudaraan dan keadilan. Tujuan utama persaudaraan dan keadilan dalam Islam diarahkan pada kepentingan kesejahteraan semua manusia. Kesejahteraan ini termasuk kepuasan bersifat fisik, karena ketenangan jiwa dan kebahagiaan mental hanya dapat dicapai dengan cara memenuhi kebutuhan jasmani dan rohani (Chapra, 2001: 56).

Bagi Șadr, sistem ekonomi Islam memiliki beberapa karakteristik dalam aspek kepemilikan multi jenis (multitype ownership), pengambilan keputusan, alokasi sumber dan kesejahteraan publik, serta larangan riba dan distribusi zakat. Menurut Sadr, ekonomi Islam memiliki konsep kepemilikan yang dikatakan sebagai kepemilikan multi jenis. Bentuk kepemilikan tersebut dirumuskan dalam 2 (dua) kelompok, yaitu bentuk kepemilikan swasta (private) dan kepemilikan bersama. Kepemilikan bersama terbagi menjadi dua bentuk kepemilikan, yaitu kepemilikan publik dan kepemilikan negara.

Dalam hal pengambilan keputusan, alokasi sumber dan kesejahteraan publik, Sadr menyatakan bahwa pemilikan negara sangat mendominasi dalam sistem ekonomi Islam. Hal ini mendorong lahirnya sebuah gagasan bahwa peran pemerintah dalam bidang ekonomi sangat penting. Adapun berkaitan dengan larangan riba dan pendistribusian zakat, Șadr berpendapat bahwa riba adalah sesuatu yang harus dijauhkan dari interaksi ekonomi masyarakat. Sedangkan zakat merupakan instrumen strategis yang dapat membantu merealisasikan kesejahteraan di tengah-tengah kehidupan masyarakat. 
Șadr juga mengupas sistem ekonomi Islam dengan sistem moneternya yang melarang adanya praktik riba (interest) dalam setiap transaksi perbankan. Pandangan Șadr bisa disebut sebagai pandangan mainstream ahli-ahli hukum Islam zaman pertengahan yang sepakat pada sebuah kesimpulan bahwa setiap jenis bunga uang adalah terlarang. Namun menurut Fazlur Rahman, bunga (interest) di kalangan perbankan (yang umumnya dipengaruhi oleh teori ekonomi klasik), mengasumsikan bahwa keseimbangan antara jumlah tabungan dan investasi modal lebih banyak dipengaruhi oleh suku bunga, dan bahwa suku bunga tetap harus ada untuk kestabilan ekonomi dan pengembangan investasi modal.

Postulat inilah yang kemudian dikritik tajam oleh Șadr (1994) dengan menyatakan, bahwa teori klasik pembungaan uang telah gagal dalam misinya, karena jumlah tabungan tidak selamanya ditentukan oleh besarnya jumlah suku bunga. Pendapat ini diperkuat oleh Gustav Cassel, seorang ekonom Yahudi, dalam Nature and Necessity of Interest (1974), bahwa jumlah besar tabungan sebenarnya lebih banyak dipengaruhi oleh income (pendapatan) yang ditabung, dan produktifitas yang optimal dari investasi modal, bukan dipengaruhi oleh bunga. Islam, dalam melarang riba, bukan hanya bersandar kepada landasan teologis saja, tetapi juga melihat pada aspek humanisme, yaitu menghindari eksploitasi yang kuat atas yang lemah, dan menekankan kesejahteraan yang adil.

\section{Teori Produksi dan Distribusi}

Dalam aktivitas produksi, Șadr (2008: 393-450) mengklasifikasikan dua aspek yang mendasari terjadinya aktivitas produksi: Pertama, aspek objektif atau aspek ilmiah yang berhubungan dengan sisi teknis dan ekonomis yang terdiri atas sarana-sarana yang digunakan, kekayaan alam yang diolah, dan kerja yang dicurahkan dalam aktivitas produksi. Aspek objektif ini berusaha menjawab masalah-masalah efisiensi teknis dan ekonomis yang berkenaan dengan 3 (tiga) pertanyaan dasar yang terkenal dengan istilah The Three Fundamental Economic Problem yang meliputi what, how dan for whom. Sisi objektif aktivitas produksi adalah subjek kajian ilmu ekonomi, baik secara khusus maupun dalam kaitannya dengan ilmu pengetahuan lainnya, guna menemukan hukum-hukum umum yang mengendalikan sarana- 
sarana produksi dan kekayaan alam. Hal itu dimaksudkan agar manusia dapat menguasai hukum-hukum tersebut dan memanfaatkannya untuk memberdayakan sisi objektif produksi secara lebih baik dan lebih sukses.

Kedua, aspek subjektif, yaitu aspek yang terdiri atas motif psikologis, tujuan yang hendak dicapai melalui aktivitas produksi, dan evaluasi aktivitas produksi menurut berbagai konsepsi keadilan yang dianut.

Selain itu, menurut Șadr, sumber asli produksi dapat dijabarkan dalam tiga kelompok, yaitu alam, modal dan kerja. Kemudian Șadr menggolongkan sumber alam yang digunakan untuk aktivitas produksi, ke dalam tiga kelompok, yakni tanah, substansi-substansi primer, dan aliran air. Dalam rangka mewujudkan pertumbuhan produksi, Șadr menawarkan dua strategi, yaitu strategi doktrinal (intelektual) dan strategi legislatif (hukum). Strategi doktrinal bertolak dari asumsi bahwa seseorang yang termotivasi untuk bekerja keras itu berarti ia telah melakukan suatu ibadah jika hal itu dilaksanakan dengan pemahaman dan niat seperti yang dinyatakan dalam Alquran. Contoh lainnya adalah meyakini bahwa melakukan pembiaran terhadap sumber-sumber pengangguran, melakukan pengeluaran mubazir dan memproduksi barang-barang haram adalah perbuatan terlarang dalam ajaran Islam. Pemikiran demikian merupakan landasan doktrinal dalam mewujudkan pertumbuhan produksi.

Untuk keberlangsungan strategi doktrinal di atas, diperlukan adanya aturan hukum yang mencakup strategi doktrinal tersebut. Beberapa strategi legislatif atau aturan hukum yang ditawarkan oleh Șadr antara lain: (1) Tanah yang menganggur dapat disita oleh negara dan negara berhak meredistribusikannya kepada orang lain yang mampu dan mau menggarapnya; (2) Larangan terhadap hima yakni memiliki tanah dengan jalan paksa; (3) Larangan kegiatan transaksi yang tidak produktif, seperti membeli dengan harga murah dan menjualnya dengan harga yang mahal tanpa bekerja; (4) Pelarangan riba, monopoli (ị̣tikār), pemusatan sirkulasi kekayaan dan melakukan tindakan yang berlebihan atau mubadhir, dan (5) Melakukan regulasi pasar dan mengkontrol situasi pasar.

Sarana-sarana di atas adalah sumbangan Islam sebagai sebuah doktrin dalam pertumbuhan produksi dan peningkatan kekayaan. Setelah memberikan sumbangan tersebut, Islam menyerahkan langkah-langkah selanjutnya 
kepada negara dengan mengkaji berbagai situasi dan kondisi objektif kehidupan ekonomi. Negara harus melakukan survei dan sensus tentang kekayaan alam yang dimilikinya. Negara juga harus mengkaji secara komprehenshif tenaga kerja dalam masyarakat serta berbagai kesulitan dan kehidupan yang mereka jalani.

Berdasarkan semua itu, dalam batas-batas doktrinal, muncullah formulasi kebijakan ekonomi yang mengarah kepada pertumbuhan produksi dan peningkatan kekayaan, yang pada akhirnya memiliki andil dalam mempermudah dan memberi rasa aman kehidupan masyarakat. Atas dasar pemikiran ini, Sạdr memahami hubungan antara agama dengan kebijakan ekonomi negara merupakan satu kesatuan yang utuh. Negara harus mematok jangka waktu tertentu untuk mencapai tujuan atau target tertentu. Kebijakan seperti ini bukan merupakan unsur dan tugas pokok agama, melainkan hasil pembumian nilai-nilai syariah oleh pemerintah.

Adapun kaitannya dengan distribusi kekayaan, Șadr membaginya dalam dua tingkatan, yaitu distribusi sumber-sumber produksi dan distribusi kekayaan produktif. Sumber-sumber produktif itu terkait dengan masalah tanah, bahan-bahan mentah, alat-alat dan mesin yang dibutuhkan untuk memproduksi beragam barang dan komoditas. Sedangkan yang termasuk dengan kekayaan produktif adalah hasil dari proses pengolahan atau hasil dari aktivitas produksi melalui kombinasi sumber-sumber produksi yang dihasilkan manusia melalui kerja. Berkenaan dengan ini, menjaga adilnya sirkulasi kekayaan dan keseimbangan harta di tengah-tengah kehidupan masyarakat, juga masuk dalam konsepsi Șadr sebagaimana pemikiran ekonom Islam lainnya.

\section{Peran Negara dan Tanggung Jawab Mewujudkan Keadilan Ekonomi}

Dewasa ini, peran pemerintah di bidang ekonomi cenderung mengamini paham laissez faire yang menjadi ruh mekanisme pasar sistem Kapitalisme. Padahal jika dilacak akar lahirnya sebuah negara adalah bermula dari adanya kontrak sosial antara masyarakat dengan negara. Dalam hal ini, masyarakat merelakan sebagian haknya untuk dibatasi dalam tata kehidupan 
bernegara yang bertujuan untuk mendapatkan perlindungan dan kesejahteraan dalam hidup. Teori kontrak sosial tersebut, sebagaimana dikemukakan oleh JJ Rosseuo, pada kenyataannya berada di bawah sistem Kapitalisme pasar yang tidak mendapatkan tempat yang cukup berarti. Hal ini berbeda dengan pemikiran Șadr tentang peran dan tanggung jawab negara di bidang ekonomi. Bagi Șadr, negara sangat jelas harus berperan aktif dalam menentukan arah kebijakan dan melakukan pengawasan terhadap interaksi ekonomi dalam suatu negara. Institusi hisbah (pengawasan) yang menjadi konsensus Șadr secara khusus merupakan bukti konkret akan hal ini.

Dalam konsep ekonomi Islam, upaya mewujudkan keadilan ekonomi harus didukung peran serta pemerintah. Dalam hal ini, pemerintah memiliki fungsi dan tanggung jawab yang tidak ringan. Tanggung jawab pemerintah dalam bidang ekonomi tersebut antara lain berkenaan dengan tiga hal, yaitu fasilitasi jaminan sosial dalam masyarakat, pencapaian keseimbangan sosial dan intervensi pemerintah dalam bidang ekonomi. Adapun fungsi pokok pemerintah di bidang ekonomi antara lain: (1) Mengatur sistem distribusi kekayaan berdasarkan pada kemauan dan kapasitas kerja masing-masing individu dalam masyarakat; (2) Mengintegrasikan aturan hukum Islam dalam setiap penggunaan dan pengelolaan sumber daya alam; dan (3) Membangun sistem kesejahteraan masyarakat melalui terjaminnya keseimbangan sosial dalam masyarakat (Ṣadr: 2008, 455-491).

Islam telah menugaskan negara untuk menyediakan jaminan sosial guna memelihara standar hidup seluruh individu dalam masyarakat. Dalam hal ini, menurut Sadr (2008) jaminan sosial tersebut terkait dengan dua hal: Pertama, negara harus memberikan setiap individu kesempatan yang luas untuk melakukan kerja produktif sehingga ia bisa memenuhi kebutuhan hidupnya dari kerja dan usahanya sendiri. Kedua, jika individu dalam kondisi tertentu tidak mampu melakukan aktivitas kerja produktif yang disebabkan oleh kemampuan individu yang berbeda-beda, maka negara wajib mengaplikasikan jaminan sosial bagi kelompok yang demikian dalam bentuk pemberian uang secara tunai untuk mencukupi kebutuhan hidupnya dan untuk memperbaiki standar kehidupannya.

Prinsip jaminan sosial dalam Islam didasarkan pada dua basis doktrinal, yaitu keharusan adanya timbal balik dalam masyarakat, dan hak 
masyarakat atas sumber daya (kekayaan) publik yang dikuasai negara. Kedua basis tersebut memiliki batas dan urgensi tersendiri yang berkenaan dengan penentuan jenis kebutuhan apa yang pemenuhannya harus dijamin, juga berkenaan dengan penetapan standar hidup minimal yang harus dijamin oleh prinsip jaminan sosial bagi setiap individu.

Konsep keseimbangan sosial yang ditawarkan oleh Șadr adalah konsep keseimbangan yang didasarkan pada dua asumsi dasar, yaitu fakta kosmik dan fakta doktrinal. Fakta kosmik merupakan suatu perbedaan yang eksis di tengah-tengah kehidupan masyarakat. Menurut Șadr, fakta kosmik adalah suatu fakta yang tidak bisa diingkari oleh siapapun bahwa setiap individu secara alamiah memiliki bakat dan potensi yang berbeda-beda. Perbedaan tersebut dalam satu titik pada akhirnya akan melahirkan perbedaan dalam kehidupan masyarakat. Dalam hal ini, perbedaan tersebut dikenal dengan strata sosial. Menurut Șadr, perbedaan yang bersifat bawaan atau kosmik tidak dapat dibenarkan karena merupakan hasil dari proses sejarah yang bersifat eksidental, sebagaimana Marx dan para pengikutnya memaknai proses tranformasi sistem kehidupan masyarakat dari tingkatan komunal menuju sistem puncak, yaitu komunisme yang berakar dari proses dialektis dalam relasi produksi. Adapun fakta doktrinal adalah hukum distribusi yang menyatakan bahwa kerja merupakan salah satu instrumen terwujudnya kepemilikan pribadi yang membawa konsekuensi atas segala sesuatu yang melekat padanya.

\section{Penutup}

Fenomena trend perkembangan ilmu ekonomi dewasa ini telah melahirkan banyak peluang sekaligus tantangan, terutama dalam upaya pengembangan ekonomi Islam. Titik kelemahan ilmu ekonomi konvensional terletak kepada paradigma sekulernya yang memisahkan antara ekonomi positif dan normatif, ketiadaan hubungan yang kokoh antara ekonomi mikro dan makro, serta pengabaian nilai-nilai moral dan etika dalam fungsi deskriptif dan prediktifnya. Oleh karena itu ilmu ekonomi Islam dapat menjadi usaha sistematis untuk melihat ulang keseluruhan persoalan ekonomi, termasuk metodologinya. 
Tawaran-tawaran pemikiran Șadr di atas tidak lepas dari kritik. Kuran adalah salah satunya. Ia mengkritik bahwa pemikiran ekonomi Șadr yang dianggap sebagai upaya penggalian dan penemuan sistem ekonomi Islam yang benar-benar baru, pada dasarnya sudah ditemukan oleh sistem ekonomi konvensional. Oleh karena itu, apa yang dilakukan oleh Șadr dengan mengklaim telah menemukan sistem ekonomi yang murni dan berbeda dengan sistem konvensional harus tetap dikaji secara proporsional sebagaimana kita mengkaji sistem Kapitalisme dan Sosialisme. Namun demikian terlepas dari kelebihan dan kekurangan, pemikiran Șadr dapat dijadikan sebagai bahan pertimbangan pengembangan ekonomi Islam ke depan. Selain itu kita perlu belajar dari kesuksesan dan kegagalan ekonomi konvensional serta memanfaatkan pendekatan-pendekatan baru yang kreatif dan inovatif, sehingga dapat mewujudkan ekonomi Islam yang rahmatan lil'alamin dalam berbagai aspeknya.

\section{Daftar Pustaka}

Afzalurrahman. 1995. Doktrin Ekonomi Islam, terj. Nastangin, Yogyakarta: Yayasan Dana Bhakti Wakaf.

Al-Nabhani, Taqyuddin. 1999. Membangun Sistem Ekonomi Alternatif Perspektif Islam, terj. Moch Maghfur Wachid. Surabaya: Risalah Gusti.

Al-Sạdr, Muhmmad Baqir. 1994. Al-Bank al-Lā Riba fí al-Islām, Beirut, Dār al Ta'āruf. , 1991. Iqtiṣādunā, Beirut: Dār al-Ta'āruf. , 1999. Falsafatunā, Terj. M. Nur Mufid bin Ali. Bandung: Mizan. , 2002. Keunggulan Ekonomi Islam, terj. M. Hashem. Jakarta: Zahra. , 2008. Buku Induk Ekonomi Islam. terj. Yudi. Jakarta: Zahra.

Chapra, M. Umar. 2006. Islam dan Tantangan Ekonomi, terj. Ikhwan Abidin Basri, Jakarta: Gema Insani Press.

Chapra, M. Umar. 2001. Masa Depan Ilmu Ekonomi: Sebuah Tinjauan Islam, terj. Ikhwan Abidin Basri, Jakarta: Gema Insani Press.

Capra, Firtjof. 1997. The Turning Point, Science, Society and The Rising Culture, New York: Bantam Book.

Efendi, Rustam. 2003. Produksi Dalam Islam. Yogyakarta: Megistra Insania. 
Khadduri, Majid. 1999. Teologi Keadilan Perspektif Islam, terj. H. Mochtar Zoerni dan Joko S. Kahhar. Surabaya: Risalah Gusti.

Mallat, Chibli. 2001. Menyegarkan "Islam" Kajian Komprehenshif Pertama atas Hidup dan Karya Muhammad Baqir al Shadr, terj. Santi Indra Astuti. Bandung: Mizan.

Mannan, M. Abdul. 1986. Islamic Economics, Theory and Practice. Cambride: Hodder and Stoughton, The Islamic Academy.

Muslehuddin, Muhammad. 2004. Economics and Islam, (edisi terj.) Yogyakarta: IRCiSoD.

Naqvi, Syed Nawab Haider. 1994. Islam, Economics and Society, London \& New York, Kegan Paul International.

Quṭb, Sayyid. 1984. Al 'Adālah al Ijtimā'iyah, terj. Afif Muhammad, Keadilan Sosial dalam Islam, Bandung: Pustaka.

Rawls, John. 2006. Teori Keadilan: Dasar-dasar Filsafat Politik untuk Mewujudkan Kesejahteraan Sosial dalam Negara, terj. Uzair Fauzan dan Heru Prasetyo, Yogyakarta: Pustaka Pelajar. 